Fu, E.S.J., Huang, J.J.S., Yang, S.J.H., \& Huang, A.Y.Q. (2012). Evaluating e-portfolio using by learning stages: A case study in an interdisciplinary program. Journal of Educational Technology

Development and Exchange, 5(2), 1-10.

\title{
Evaluating e-portfolio Using by Learning Stages: A Case Study in an Interdisciplinary Program
}

\author{
Ellis S. J. Fu \\ Central University \\ Jeff J.S. Huang \\ Hwa Hsia Institute of Technology \\ Stephen J.H. Yang \\ Anna Y.Q. Huang \\ Central University
}

\begin{abstract}
This study conducts an investigation of posts in the e-portfolio platform of the program: "The interdisciplinary training program for talented college students in science." Participants in this program were supposed to show their learning portfolios on this platform. Among the 2150 registered students, we randomly selected 126 students who have made at least 3 posts to become the target sample. By identifying the learning stages and posting styles shown by their posts, we find that students are mostly in the surface learning stages and weak in completing their learning portfolios. The results suggest that more strategies should be learned in e-portfolio use. In addition, some related issues about learning performance are also discussed.
\end{abstract}

Keywords: interdisciplinary, e-portfolio, reflection, content analysis

\section{Introduction}

\subsection{Background}

The background of this study is an interdisciplinary program conducted by the educational sector in Taiwan. The main purpose of this program is to provide opportunities for undergraduates in different disciplines to interact with each other by studying a topic covering at least two scientific domains. For example, a project named "Studies on the shoaling process of dual tsunami waves" was implemented by the students in the Earth Science department and the Civil Engineering department. During the process of the project, supervisors would arrange some workshops, laboratory visits, or even field trips to train these students. At the end of the project, those students are supposed to present their learning results by completing written and oral reports. An e-portfolio platform was provided for those who attended this program, and they were encouraged to document their learning process, record reflections, and write about their feelings or interested events on this platform. In this sense, the learning representation of these 
students can be assessed by analyzing their e-portfolio posts.

\subsection{E-Portfolio Platform}

An e-portfolio platform is a Webbased information system for demonstrating learners' learning process over time (Huang, Yang, Chiang, \& Tseng, 2012). Students can use it to record their learning experiences, works, extra curriculum experiences, practice training, and so on. The main purpose of e-portfolio is to help learners in all ages to reflect upon their learning experience. Specifically, used to improve the quality of teaching and learning, an e-portfolio system not only provides teachers and students a way to show what they have achieved and learned (assessment of learning), but also provides them an opportunity to reflect upon their learning by recording learning results (assessment for learning), and hence, encourage students' self-reflection through learning activities (Dennis \& Hardy, 2006; Désirée, Beijaard, \& Verloop, 2007).

Recently, e-portfolio use in universities has become more popular. Regis University (2005) divided e-portfolio into three types: developmental, assessment, and showcase portfolios. Developmental portfolios emphasize students' learning records, self-assessment, and reflection/feedback. Assessment portfolios demonstrate students' competence and skills and evaluate their learning outcomes. Showcase portfolios present students' exemplary work and their skills. These three different types of e-portfolio system may be mixed to accomplish different purpose of learning. In the context of nonformal learning, learners can assess and recognize knowledge through community and workplace experience by using e-portfolio system. In the context of formal education and training, e-portfolio can be considered as a teaching tool, a learning management tool, and an alternative form of learning assessment (Barker, 2006).

In general, an e-portfolio has three types of purposes. First, it helps students to show and reflect upon their learning. Second, it provides teachers with a way of formative assessment other than standardized testing, by capturing a more holistic nature of students' learning. Third, it provides an environment to demonstrate learners' competence to potential employers in job applications (Chau \& Cheng, 2010). In this study, the focus is on the role of showing and reflecting on the learning process. Bonnie (2006) mentioned that an e-portfolio without reflection is merely storage. The reflection process guides students to construct knowledge through experience and feedback. There are many studies investigating the benefits of e-portfolios as a reflective learning tool on students' learning (Adams, Swicegood, \& Lynch, 2004; Evans, Daniel, Mikovch, Metze, \& Norman, 2006; Wall, Higgins, Miller, \& Packard, 2006). However, there has been far less research on evaluating learning stages shown by the e-portfolio posts. This study tries to work on this approach, especially in using e-portfolio as an initial event in higher education in Taiwan.

\subsection{Reflection \& Deep Learning}

"Reflection" is a common word used in learning. However, the definition of this word is not settled until now. It involves complicated mental processing of issues (Deway, 1933; King \& Kitchener, 1994). The common-sense view of reflection is that it is a mental process that is couched in a framework of purpose or outcome (Moon, 1999). For example, while facing new learning material, a student might recall some events or feelings she/he has experienced. Then she/he might 
organize the perceived information to decide the learning approach to that material. It is a representation of reflection. However, there are high levels of reflection which we call "deep learning," and also low levels of reflection that could only be called "surface learning." Moon (1999) described the five learning stages covering noticing, making sense, making meaning, working with meaning, and transformative learning to represent a learning map. She classified the first three learning stages to be "surface learning" and the last two learning stages to be "deep learning." We use her ideas to form the coding scheme in the content analysis. At the same time, the posting styles of all participants are also discussed to shed light on the e-portfolio-based learning. Specifically, the study sought to address the following two questions:

- What are the learning stages shown by these students in this interdisciplinary program?

- What were the e-portfolio use styles of these students?

\section{System Outline}

The home page of the e-portfolio system in this study can be seen in Figure 1. The two items highlighted by the red line are the most important functions of this platform. First, the "project portfolio" provides the space for participants to upload their learning files or works during the project implementation. However, students in this program either did not know how to use or were reluctant to upload their portfolios. As a result, only several students had ever used this function, and moreover, they just put all related email records of the project and some meeting agenda on it. Thus, the main data source for this study came only from the "learning blog."

The "learning blog" function highlighted in Figure 1 was the space for students to show their reflection, their learning activities records, learning diaries, and so on. It is also a place for social interaction. Figure 2 shows the homepage of the learning blogs. There are three main lists in this page: the latest posts, the most active blogs, and the latest created blogs. The most active blogs were ordered by the number of comments replied.

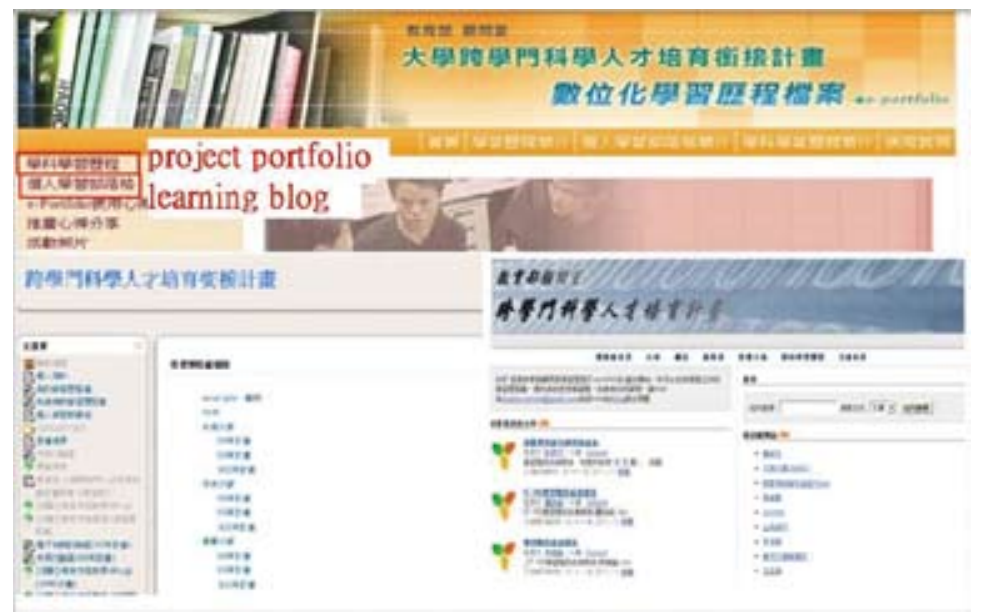

Figure 1. Homepage of the e-portfolio system. 


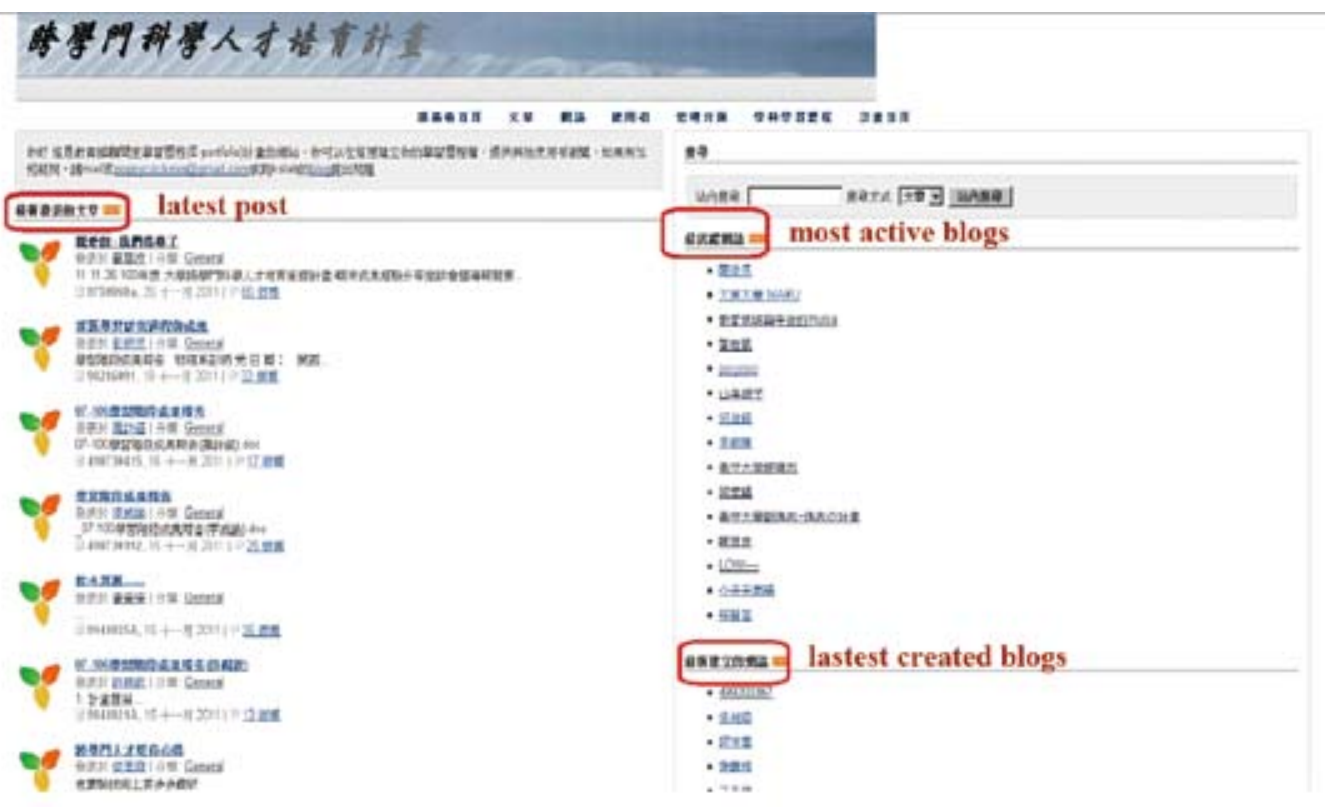

Figure 2. Learning blog homepage

Although the leaders in this program had trained many assistants to help every student become familiar with the functions of this e-portfolio platform, there were only a small number of students who have ever used it as part of the project learning. As a result, participants who have posted over three posts were no more than 300 . This is also an issue worth studying.

\section{Method}

\subsection{Participants}

The participants in this study were 126 undergraduates who attended the program.
This interdisciplinary training program for talented college students in science was implemented from 2009 to 2011. There were about 700 students attending this program each year; hence 2150 total students have registered for the e-portfolio platform of this program. However, most of them are not active users. The participants were randomly chosen from those who have made at least 3 posts. The demographic of the participants is shown in Table 1. Most of the participants came from the colleges of science or the colleges of engineering. The others came from the colleges of medicine. Male and female are almost half-and-half (53.2\%: 46.8\%).

Table 1. Frequency for the Participants

\begin{tabular}{ccccc}
\hline & $\begin{array}{c}\text { College of } \\
\text { Science }\end{array}$ & $\begin{array}{c}\text { College of } \\
\text { Engineering }\end{array}$ & $\begin{array}{c}\text { College of } \\
\text { Medicine }\end{array}$ & Total \\
\hline Male & 19 & 40 & 8 & 67 \\
Female & 21 & 33 & 5 & 59 \\
\hline
\end{tabular}


Table 2. Coding Guide for Learning Stages

\begin{tabular}{|c|c|c|c|}
\hline Notation & Code & Explanation & Example \\
\hline L1 & Noticing & $\begin{array}{l}\text { 1. There is an instant feeling } \\
\text { about the learning } \\
\text { material. }\end{array}$ & $\begin{array}{l}\text { 1. I am excited about this. } \\
2 \text {. I will hold this in mind. }\end{array}$ \\
\hline L2 & Making sense & $\begin{array}{l}\text { 1. Becoming aware of } \\
\text { coherency in the material } \\
\text { of learning. } \\
\text { 2. Reorganization of material } \\
\text { that is not understood. }\end{array}$ & $\begin{array}{l}\text { 1. I think we have enough facts } \\
\text { to work out the problem. } \\
\text { 2. I think this kind of chemical } \\
\text { compound belongs to that } \\
\text { group. }\end{array}$ \\
\hline L3 & $\begin{array}{l}\text { Making } \\
\text { meaning }\end{array}$ & $\begin{array}{l}\text { 1. Making the appreciated } \\
\text { links in understanding. } \\
\text { 2. Showing a holistic view of } \\
\text { the subject matter. }\end{array}$ & $\begin{array}{l}\text { 1. How does this idea match } \\
\text { what we have considered. } \\
\text { 2. I know the reasons why I } \\
\text { must do it in this way. }\end{array}$ \\
\hline L4 & $\begin{array}{l}\text { Working with } \\
\text { meaning }\end{array}$ & $\begin{array}{l}\text { 1. Summary. } \\
\text { 2. Critical analysis } \\
\text { 3. Working with ideas in a } \\
\text { discipline. } \\
\text { 4. The processing that } \\
\text { enables planning. } \\
\text { 5. Making a judgment. }\end{array}$ & $\begin{array}{l}\text { 1. Give appreciative } \\
\text { explanations. } \\
\text { 2. I am working out how to } \\
\text { present my ideas so that they } \\
\text { can understand. }\end{array}$ \\
\hline L5 & $\begin{array}{l}\text { Transformative } \\
\text { learning }\end{array}$ & $\begin{array}{l}\text { 1. Evaluating their frames } \\
\text { of references, the nature } \\
\text { of their own and others' } \\
\text { knowledge, and the } \\
\text { process of knowing itself. } \\
\text { 2. Self-motivated and self- } \\
\text { motivating. }\end{array}$ & $\begin{array}{l}\text { 1. I can see that my view was } \\
\text { wrong in the past. Now, I am } \\
\text { reconsidering the situation. } \\
\text { 2. Someone helped me look at it } \\
\text { in a completely new light. } \\
\text { 3. I am critical of the whole of } \\
\text { our approach. Let me explain } \\
\text { now. }\end{array}$ \\
\hline
\end{tabular}

\subsection{Coding Scheme}

Table 2 shows the coding scheme used for identifying the learning performance of participants. For example, if the sentence "I am excited about this" is found in one's post, an "L1" will be ascribed to this participant. After coding all the sentences representing the learning stages, the researchers identify each participant with her/his highest level of learning stage, because a higher learning stage is built on the lower stages. 


\subsection{Data Collection}

For each participant, the researchers first counted the number of posts she/he wrote, and then coded the sentences that showed some learning stages correspondently. The researchers also classified the posting styles into five categories. To test the reliability, the first two authors read all the articles of a sample of 30 participants and discussed the inconsistent opinions until got a perfect interrater consistency by Cohen's $\kappa>0.9$. Then, the first author continued to finish the remained.

\section{Results}

\subsection{Data Description of Learning Stages}

Table 3 shows the posting numbers of the participants. For example, there are 48 participants who just post 3-5 posts and only 6 participants that have posted more than 20 posts. The largest posting number is 45 and there are 1089 posts among these 126 participants. In Table 4, the learning performance shown by the posts of the participants were mostly in the first three stages. Only one fourth $(32 / 126)$ of them showed the "deep learning" stages in their posts. A correlation coefficient 0.365 was calculated between the posting number and the learning stages (1 for L1, 2 for L2, and so on). It appears that a larger number of posts made do not always guarantee deep learning stages.

\subsection{The Posting Styles}

By detailed reading of the participants' posts, the researchers also classified learners' posting styles into five categories. The result is shown in Table 5. Those who were classified into the table are easily recognized by their posts. However, 5 participants showed two categories simultaneously and were counted twice.

\section{Discussion}

\subsection{The Learning Stages Shown By the Posts}

In this e-portfolio platform, participants are not pressured in submitting a formal assessment. E-portfolios provide learners with encouragement, and are not seen as punishment. They are free to post articles based upon their reflection of the learning process. Hence, it can be seen as a natural way of assessment. As Table 4 shows, the learning performance of participants is mainly restricted in the first three stages. The researchers have three speculations about this result. First, this phenomenon could be inferred from their posting styles. For example, there are 36 of

Table 3. The Posting Number

\begin{tabular}{lllll}
\hline $3-5$ & $6-10$ & $11-15$ & $16-20$ & $21-$ \\
\hline 48 & 48 & 12 & 13 & 6 \\
\hline $\mathrm{n}=126$ & & & &
\end{tabular}

Table 4. The Learning Stage Performance of Participants

\begin{tabular}{lllll}
\hline L1 & L2 & L3 & L4 & L5 \\
\hline 35 & 26 & 33 & 19 & 13 \\
\hline $\mathrm{n}=126$ & & & &
\end{tabular}


Table 5. Posting Styles

\begin{tabular}{|c|c|c|}
\hline Category & Explanation & Count \\
\hline Visual style & $\begin{array}{l}\text { Expressed their learning or interested events } \\
\text { mostly through pictures or films; only used few } \\
\text { or no words. }\end{array}$ & 21 \\
\hline $\begin{array}{l}\text { Detailed activity } \\
\text { recording style }\end{array}$ & $\begin{array}{l}\text { For each learning activity, they detailed and } \\
\text { recorded the process and procedures. However, } \\
\text { the reflection was few. }\end{array}$ & 18 \\
\hline $\begin{array}{l}\text { Feelings sharing } \\
\text { style }\end{array}$ & $\begin{array}{l}\text { Their posts were mainly emotional expression } \\
\text { about the project learning. Some gave critical } \\
\text { comments. }\end{array}$ & 55 \\
\hline Events records style & $\begin{array}{l}\text { They just recorded the events of visiting } \\
\text { laboratories or field trips. Pictures were often } \\
\text { supported with explanations. }\end{array}$ & 22 \\
\hline $\begin{array}{l}\text { Hobby collection } \\
\text { Style }\end{array}$ & $\begin{array}{l}\text { Including new knowledge, new songs, contest } \\
\text { records, and jokes. }\end{array}$ & 15 \\
\hline
\end{tabular}

participants, including the visual style and hobby collection style, which did not do any reflection in their posts. They are all classified into the L1. It might be that they have no idea of how to use e-portfolio to enhance learning or are reluctant to show their leaning performance on the platform. Second, reflection, especially deep reflection, does not always occur among undergraduates in Taiwan. It has been long claimed that undergraduates in Taiwan lack critical thinking ability, which is a main issue in deep learning. Third, the participants who attended this program were chosen by the professor in their department. They are, to some extent, excellent in their learning performance. However, their e-portfolio posts did not show a consistent result to their ordinary learning. These are all important issues worthy to be studied.

\subsection{The Posting Styles}

E-portfolio use in higher education in Taiwan has occured only quite recently. Many students might be familiar with blogs, but do not know the difference between blogs and e-portfolios. To some degree, they are not so different. However, a learning based e-portfolio has its own focus and purposes as mentioned in the introduction section. In Table 5, the researchers found that some of their posting styles seem as if they are writing 
blogs. For example, some just post pictures and films with no words. For an initial try, the blog style writing does not cause so many problems. However, for the specific goals of an e-portfolio, students should find a way to represent his/her learning process and progress for future use. In this sense, the professors should take his/her responsibilities to help guide students in their e-portfolio use.

\section{Conclusions and Suggestions}

Several findings are concluded from the current study. First, the researchers found that three-fourth of participants are in the first three learning stages namely in noticing, making sense, and making meaning. Second, after examining the post's content, many of them just posted pictures and films with no words or comments to explain why these were there.. Finally, the active users of this platform are just a few, documenting lack of participation and motivation to use the system.

The findings in this study have some educational implications for e-portfolio use as listed in the following:

According to our observation, the results showed that most of those students did not show any reflection and critical thinking skills in their e-portfolio posts. There are two possibilities. First, they might lack those abilities. Second, they might not want to show their reflective thoughts. For the first reason, we suggest that instructors should pay attention to this occurrence. Because this is not an uncommon phenomenon and has long been argued, the instructors should take the responsibility to help students foster these abilities. For the second reason, it might be the preferred learning habit students want to maintain. Many students are not easy to show their real learning achievement in public, say a public learning platform like e-portfolio.
They think thoughts belong to their privacy. The data in this study might reflect some of these conditions. It is not an easy thing to deal with, because the habit has been long ingrained in the culture. However, this can be a nice example for system designers and instructors to reflect. How to build a system to match users' habit? How to make students make good use of the system. This all requires further research.

Chau and Cheng (2010) claimed that e-portfolio practice could follow a three-phase cycle of learning through planning, monitoring, and reflecting. We suggest that teachers should guide their students in e-portfolio use following the three-phase cycle. Then, it could be possible for students to use e-portfolio with ease, and the more advanced learning skills can be implemented later.

The active users of this platform are just a few as shown in Table 3. This phenomenon could result in that the social interaction on this platform is weak, and hence, the users will lose their aspiration to post articles. Although the encouragement by supervisors and the education sector have been made, it still could not really motivate students. A stronger strategy must be adopted. For example, the association with grade in this platform is none. If some mechanism could be built to increase grade level in this program we think e-portfolio use will improve.

In our opinion, e-portfolio use requires teachers and students to change their routines and mentality. For one thing, students should recognize the usefulness of e-portfolios. On the other hand, the educational sectors should start to take e-portfolios as a formative assessment associated with grades. Lack of any one side will result in e-portfolio use to become demoted in higher education in Taiwan as an alternative form of assessment. 


\section{References}

Adams, P.W., Swicegood, P. R., \& Lynch, S. A. (2004). The diagnostician's portfolio: A tool for evaluation and reflection. Assessment for Effective Intervention, 29, 53-66.

Barrett, H. (2000). Create your own electronic portfolio. Learning \& Leading with Technology, 27(7), 14-21.

Barker, K. C. (2006). Environmental scan: Overview of the ePortfolio in general and in the workplace specifically. Retrieved on October 20, 2006 from http://www. FuturEd.com

Bonnie, R. (2006). Mining for Meaning: Teaching Students How to Reflect. In Ali Jafari \& Catherine Kaufman (Eds.), Handbook of research on ePortfolios (pp. 90 - 101). Hershey, PA: IGI Global.

Chau, J., \& Cheng, G. (2010). Towards understanding the potential of e-portfolios for independent learning: A qualitative study. Australasian Journal of Education Technology, 26(7). 932-950.

Deway, J. (1933). How We Think. DC Health and $\mathrm{CO}$, Boston, MA.

Dennis, C., \& Hardy J. (2006). Development of a model to advance the uptake of e-portfolios for undergraduates in teacher education and registered nurse preparation: An exemplar of best practice. In E. Pearson \& P. Bohman (Eds.), Proceedings of World Conference on Educational Multimedia, Hypermedia and Telecommunications 2006 (pp. 248-253). Chesapeake, VA: AACE.

Désirée, D. M.-L., Beijaard, D., \& Verloop, N. (2007). The portfolio as a tool for stimulating reflection by student teachers. Teaching and Teacher Education, 23, 47-62.

Evans, S., Daniel, T., Mikovch, A., Metze, \& Norman, A. (2006). The use of technology in portfolio assessment of teacher education candidates. Journal of
Technology and Teacher Education, 14(1) 5-27.

Huang, J.J.S., Yang, S.J.H., Chiang, P.Y.F., \& Tseng, L.S.Y. (2012). Building an e-Portfolio learning model: Goal orientation and metacognitive strategies. Knowledge management and e-Learning, 4(1), 16-36.

Huang J.J.S., Yang, S.J.H., \& Chang, M.C.W. (2011). The Effect of ePortfolio satisfaction on students' learning motivation and Internet self-efficacy. The Journal of Educational Technology Development and Exchange, 4(1), 103-118.

King, P., \& Kitchener, K. (1994). Developing Reflective Judgement. San Francisco, CA: Jossey-Bass.

Moon, J. A. (1999). Reflection in Learning \& Professional Development. UK: Kogan Page.

Olatz, L.F., \& Jose Luis, R.I. (2009). Investigating university students' adaptation to a digital learner course portfolio. Computers \& education, 52(3), 608-616.

Wall, K.,Higgins, S.,Miller, J., \& Packard,N. (2006). Developing digital portfolios: Investigating how digital portfolios can facilitate pupil talk about learning. Technology, Pedagogy and Education, 15, 261-273.

\section{Acknowledgements}

This work is supported by Science Council of Taiwan under grants NSC 101-2511-S-008-001 and NSC 101-2511-S-146 -001, the Research Center for Science \& Technology for Learning of the University System of Taiwan. 


\section{Contact the Authors}

Ellis S. J. Fu

Central University

Email: ellisfu@cc.ncu.edu.tw

\section{Jeff J.S. Huang}

Hwa Hsia Institute of Technology

Email: Jeff@cc.hwh.edu.tw

\section{Stephen J.H. Yang*}

Central University

Email: jhyang@csie.ncu.edu.tw

\section{Anna Y.Q. Huang}

Central University

Email: u9115903@ccms.nkfust.edu.tw

* Corresponding Author 